\title{
Antipyretic Medication for a Feverish Planet
}

\author{
Markus Stoffel $^{1,2,3}$ (D) David B. Stephenson ${ }^{4} \cdot \operatorname{Jim}$ M. Haywood $^{4,5}$
}

Received: 25 September 2020 / Accepted: 14 October 2020 / Published online: 2 November 2020

(c) The Author(s) 2020

As the coronavirus pandemic continues to unfold at a staggering pace, $\mathrm{CO}_{2}$ emissions are in for a sharp, if temporary, decline estimated at 7\% of the 2019 annual emissions (Le Quéré et al. 2020; Carbon Brief 2020; Forster et al. 2020). Even if this reduction is substantial, it will not suffice to reach the $1.5^{\circ} \mathrm{C}$ global temperature target of the 2015 Paris Conference of Parties Agreement (COP, Brown et al. 2019), as a reduction by $7.6 \%$ would be needed every year from today to reach net-zero emissions by 2050 (Sachs et al. 2016). Therefore, once the pandemic and ensuing economic lethargy are over, societies will need to make a crucial choice on how to reach the climate goals defined at the COP. Global emissions could resume if nations decided to lean heavily on fossil energy sources to rebuild their economies (Henry et al. 2020; Ou et al. 2020). Under different leadership, strong governmental support for clean energy could tilt major economies towards a greener, more climate-friendly direction (Barbier 2020; Carbon Brief 2020; Rosenbloom and Markard 2020; Andrijevic et al. 2020).

Markus Stoffel

Markus.Stoffel@unige.ch

David B. Stephenson

D.B.Stephenson@exeter.ac.uk

Jim M. Haywood

jim.haywood@metoffice.gov.uk

1 Climate Change Impacts and Risks in the Anthropocene (C-CIA), Institute for Environmental Sciences, University of Geneva, 66 Boulevard Carl-Vogt, 1205 Geneva, Switzerland

2 Dendrolab.ch, Department of Earth Sciences, University of Geneva, 13 rue des Maraîchers, 1205 Geneva, Switzerland

3 Department F.-A. Forel for Environmental and Aquatic Sciences, University of Geneva, 66 Boulevard Carl-Vogt, 1205 Geneva, Switzerland

4 College of Engineering, Mathematics and Physical Sciences, University of Exeter, Exeter EX4 4QF, UK

5 Earth System and Mitigation Science, Met Office Hadley Centre, Exeter EX1 3PB, UK
Back in 1992, the Intergovernmental Panel on Climate Change (IPCC) forecast carbon dioxide $\left(\mathrm{CO}_{2}\right)$ concentrations under their 'IS92a best guess' scenario (Nakicenovic et al. 2003). These predictions have proved remarkably accurate; an analysis of the mean $\mathrm{CO}_{2}$ concentrations over the past thirty years from the two models available at that time (for details see IPCC 2020) indicates that they are never in error by more than $1.5 \mathrm{ppmv}$ when compared to $\mathrm{CO}_{2}$ observations (NOAA 2020). $\mathrm{CO}_{2}$ concentrations are currently increasing at a rate of around $0.5 \%$ per annum; if this continues (as they have for the last 50 years; Showstack 2013), atmospheric concentrations will rise from around 411 ppmv at current levels (their highest for the last 3 million years) to $611 \mathrm{ppmv}$ by 2100 (i.e. $411 \mathrm{ppmv} \times 0.5 \%$ annual increase $\times 80$ years). The IS92a scenario, that has proved so accurate over the last thirty years, suggests an even more pessimistic 713 ppmv (Houghton et al. 1995; IPCC 2020). Given the remarkable validation and future projections of $\mathrm{CO}_{2}$ concentrations, humanity cannot say that they have not been warned of the impact that their activities are having. The scientific consensus is that, given current mitigation efforts, the Paris Agreement target of limiting Global Mean Surface Temperature (GMST) warming to $1.5^{\circ} \mathrm{C}$ (or even $2{ }^{\circ} \mathrm{C}$; Masson-Delmotte et al. 2018) above pre-industrial values will be missed. Even if global warming continues to increase at the current rate of around $0.2{ }^{\circ} \mathrm{C}$ per decade, which is below the climate projection levels, the $1.5^{\circ} \mathrm{C}$ threshold will be exceeded by 2040-50 (Masson-Delmotte et al. 2018). The above facts unfortunately lead to the conclusion that some governments-rather than reducing emissions drastically - may soon start to consider implementing the unpalatable option of solar radiation management geoengineering (Parson 2017; Schubert 2019). Although it may be a foul-tasting medicine, it is considered to provide considerable relief from the ever-increasing catalogue of damaging extreme events (Jones et al. 2018; Irvine et al. 2019; Irvine and Keith 2020).

Clear evidence exists that human-induced GMST increases have already caused an increase in the frequency and intensity of heavy precipitation events at many locations 
across the globe, as well as a substantial increase of drought and flood risks in many arid and semi-arid regions (Myhre et al. 2019; Atif et al 2020; Tabari 2020; Yiwei et al. 2020). Assessments of projected future climate changes show that any further warming will increase the probability for unprecedented extreme weather and climate events (MassonDelmotte et al. 2018; Myhre et al. 2019). While limiting global warming to $1.5^{\circ} \mathrm{C}$ may seem only marginally different to limiting it to $2{ }^{\circ} \mathrm{C}$, there are substantially larger probabilities of extreme events occurring under $2{ }^{\circ} \mathrm{C}$ scenarios (Kharin et al. 2018). Indeed, limiting warming to $1.5^{\circ} \mathrm{C}$ above pre-industrial levels would (a) result in around half a billion fewer people being frequently exposed to extreme heatwaves, (b) reduce the risk of a further increase in frequency and intensity of heavy precipitation events, and (c) substantially reduce the probability of extreme drought and water scarcity (Masson-Delmotte et al. 2018). The number of category 4 and 5 tropical cyclones is also expected to increase in a warmer climate (Jones et al. 2017, 2018; Knutson et al. 2020). With global warming of $2{ }^{\circ} \mathrm{C}$, risks across the energy, food, and water sectors will increase compared to the $1.5^{\circ} \mathrm{C}$ target, overlapping spatially and temporally, and thereby exacerbate climate-induced hazards, exposures, and vulnerabilities. As a result, substantially larger proportions of people would become exposed and susceptible to poverty with further warming, especially in Africa and Asia (Masson-Delmotte et al. 2018). In addition, the IPCC also notes that rising GHG emissions will raise global sea level by more than a metre by 2100 . Even under more favourable scenarios, cities, such as Los Angeles and Miami, might face a "100-year" coastal flood every year by 2050 (MassonDelmotte et al. 2018). Should humanity fail to prevent the loss of major Antarctic and Greenland ice masses, future generations would see far worse. Furthermore, a majority of current climate models seem to underestimate the "extremeness" of impacts, namely in the agricultural sector, terrestrial ecosystems, or heat-related human mortality (Schewe et al. 2019). Given that without draconian mitigation strategies, in the authors' opinions, both the $1.5^{\circ} \mathrm{C}$ and $2{ }^{\circ} \mathrm{C}$ targets defined in the Paris Agreement are likely be missed, society will be exposed to increasing losses and disasters from more frequent and intense catastrophic weather extreme events, for example, events similar or even more powerful than the 2019 Hurricane Dorian and Typhoon Hagibis (Tay et al. 2020).

If greenhouse gas emissions are not reduced fast enough to avoid overshooting the Paris targets, then it seems not unlikely that future governments may well consider deploying "geoengineering" (also referred to as "climate intervention or "climate repair"); with the aim to decelerate the rate of global warming and to buy more time for mitigation and adaptation, thereby reducing risk from climaterelated losses. One of the most promising approaches is
Solar Radiation Management (SRM), which aims to reduce the amount of solar radiation reaching the Earth's surface (The Royal Society 2009; Lawrence et al. 2018). Owing to considerations of effectiveness, cost, technical feasibility and timeliness (e.g. The Royal Society 2009), the two most widely discussed forms of SRM are the deliberate injection of aerosol particles or their precursors into the stratosphere (i.e. stratospheric aerosol injection, e.g. Robock et al. 2009; Kravitz et al. 2011) and the deliberate injection of aerosol particles into low-lying stratocumulus clouds, with the aim to increase their reflectivity (so-called marine cloud brightening, e.g. Jones et al. 2011; Latham et al. 2012; Stjern et al. 2018). Both processes are known to cool the planet and occur naturally via volcanic emissions of sulphate-aerosol-forming sulphur dioxide $\left(\mathrm{SO}_{2}\right)$ that are either explosive (emissions into the stratosphere, e.g. Soden et al. 2002) or passive (emissions into the lower troposphere, e.g. Malavelle et al. 2017).

For the last decade, models used in assessing global warming have also been making increasingly sophisticated assessments of the likely impacts of SRM. Early experiments involved relatively simple idealized reductions in the solar output (i.e. simply turned down the sun) to offset the entire future global warming from increases in greenhouse gases (Kravitz et al. 2011, 2013), with assessments of reductions of climate extremes in multi-model ensembles (Irvine et al. 2019). While useful, these multi-model assessments are ultimately limited by their idealized treatment of SRM.

Only the most foolhardy would suggest utilizing offsetting an ever-increasing warming via injection of an everincreasing veil of stratospheric sulphate aerosol. This approach is fallacious for two well-established reasons. First, sophisticated stratospheric aerosol modelling has revealed less and less cooling per unit of $\mathrm{SO}_{2}$ injection, therefore diminishing returns that underline the need for comprehensive decarbonization during any stratospheric aerosol injection deployment period (Niemeier and Timmreck 2015). Second, such a strategy will neglect the rapid return to the non-geoengineered climate should SRM be halted for any reason (Jones et al. 2013). Compressing the climate change that the Earth would experience under global warming into less than a decade would likely devastate many ecosystems (Trisos et al. 2018).

In addition to these two major roadblocks for offsetting a large amount of global warming by SRM, detailed modelling studies have elucidated how NOT to deploy geoengineering. It has been shown that any stratospheric aerosol injection strategy that targets one hemisphere in isolation will lead to changes in the cross-equatorial energy and moisture flows that could have potentially devastating consequences on tropical rainfall patterns and associated droughts, floods and hurricane frequency and intensity (Haywood et al. 2013; Jones et al. 2017). Efficient marine 
cloud brightening relies on increasing the cloud albedo through a combination of increasing their reflectivity (the first indirect effect) and increasing cloud fraction (second indirect effect) (Stjern et al. 2018). However, new observational evidence suggests that the second indirect effect would be strongly buffered in the climate system and that it would do little to contribute to increased reflection (Malavelle et al. 2017; Toll et al. 2019). Model results suggest that any marine cloud brightening strategy that targets a particular cloud deck can not only alter the meridional cross-equatorial energy and moisture flows but can induce changes in mean-zonal Walker-circulation flows as well, with potential devastating consequences for continentalscale rainfall (Jones et al. 2009). Based on the above, one has to conclude that deliberate marine cloud brightening has many drawbacks compared to deliberate stratospheric aerosol injection. Marine cloud brightening may be ineffective at reducing global mean temperatures, and even if it should be effective, it will tend to preferentially cool ocean areas rather than land areas, and any geographically inhomogeneous forcing may force undesirable dynamical changes in circulation and precipitation patterns (e.g. Jones et al. 2009, 2011).

Learning from past climate model simulations of how not to perform SRM, approaches have matured from idealized experiments to include assessments where the global warming from the various Representative Concentration Pathway (RCP) scenarios are limited to the specific climate targets of the Paris Agreement via stratospheric aerosol injections (Tilmes et al. 2016; Jones et al. 2018; Irvine et al. 2019; Irvine and Keith 2020). These single-model studies suggest that under virtually all Representative Concentration Pathway (RCP) scenarios, risks identified in key weather and climate extremes (e.g., water stress, heatwaves, or the number and intensity of large Atlantic hurricanes) are ameliorated significantly.

Net zero carbon emissions clearly have to remain the goal to be achieved by humanity, as it remains the only way to mitigate climate change safely and sustainably in the long run and to reduce the plethora of risks which scale nonlinearly with each degree of mean global warming (Fig. 1). However, given that the current mitigation activities are wholly incompatible with both of the Paris Agreement targets, governments will sooner or later have to acknowledge the need for back-up plans. In preparation for such an eventuality, it is entirely appropriate to develop model-based research into the physical science of SRM, to fill remaining gaps in scientific knowledge. The first step would be to accept failure at reigning in $\mathrm{CO}_{2}$ emissions despite decades of increasingly alarming evidence of global warming and its associated impacts. New Geo-Engineering Model Inter-comparison Project (GeoMIP) simulations with more sophisticated stratospheric sulphur cycle modelling coupled to more policy-relevant deployment scenarios are already underway (Jones et al. 2020; Kravitz et al. 2020). These model simulations are not only able to assess the amount of $\mathrm{SO}_{2}$ needed to achieve meaningful reductions in global mean surface temperatures, but also to assess the detailed regional and temporal response of the climate system at unprecedented detail. Many other aspects would need to be addressed from a scientific standpoint to increase confidence about possible and hitherto ignored side effects of SRM. These should include the search for potential alternatives to currently proposed marine cloud brightening and stratospheric aerosol injection strategies, state-of-the-art multimodel assessments of stratospheric aerosol injection scenarios in different seasons, different latitudes and altitudes, and at different emission rates. In addition, and despite obvious
Fig. 1 Global warming expected for no mitigation, current mitigation scenarios, mitigation including aggressive measures to achieve next zero carbon emissions and a mitigation, and the use of SRM to 'peak shave' global mean temperatures to maintain global mean temperatures at $1.5^{\circ} \mathrm{C}$ as per the Paris COP target ( adapted from Jones et al. 2018). The analysis of risk in this case is based on the frequency of extreme precipitation per degree of mean global warming (Myhre et al. 2019)

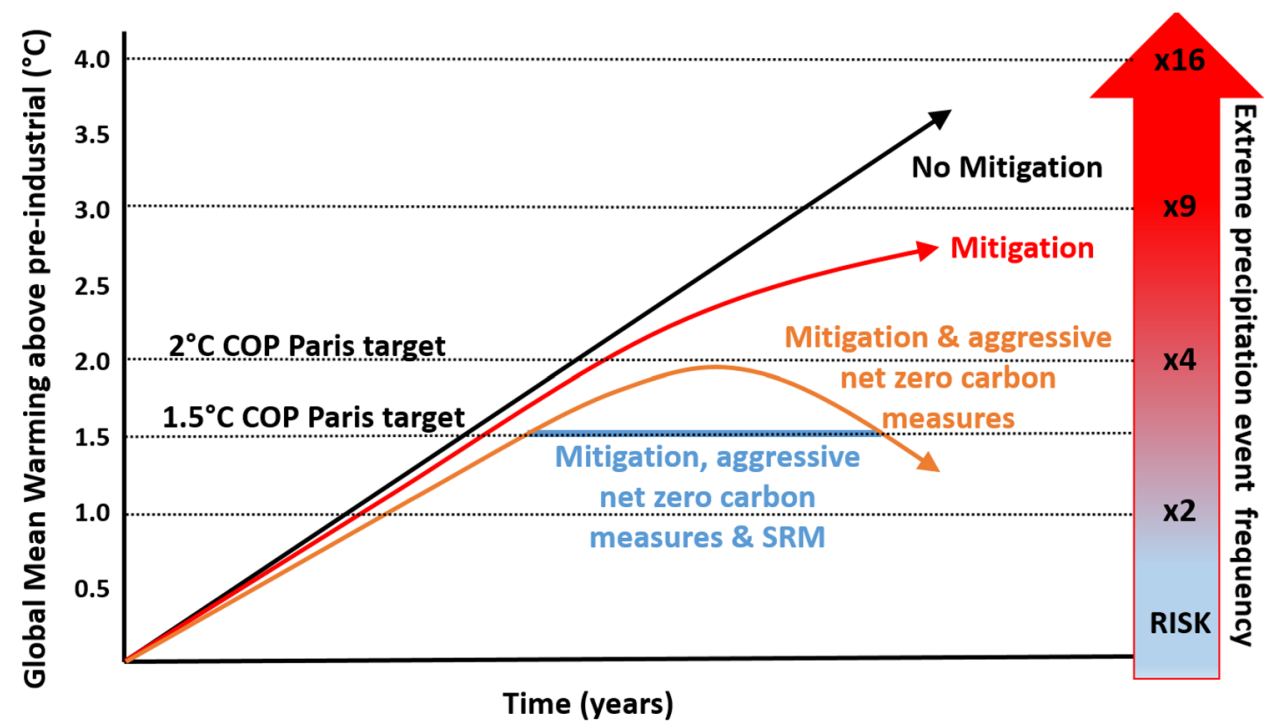


differences, comparisons of model outputs with observations from volcanic eruptions as natural analogues (Robock et al. 2010, 2013; Stoffel et al. 2015) would be a vital component, namely regarding the injection and evolution of $\mathrm{SO}_{2}$ into the stratosphere by explosive eruptions as an analogue for stratospheric aerosol injection or the natural release of $\mathrm{SO}_{2}$ during volcanic degassing events as an analogue for marine cloud brightening. Such natural events provide the necessary observational data for validating the fidelity of our models.

Even if models should reach sufficient quality, one would still need to determine the monetary costs of long-term efforts associated with the different SRM methods. From a purely socio-economic perspective, the development, deployment and operational costs obviously need better quantification, but the socio-economic costs that could be avoided by reducing the risk of damaging extreme floods, droughts, heatwaves or tropical storms also need evaluating. While an assessment of physical damage of such disasters can be assessed to reasonable accuracy with data from insurance industry, any assessment of the actions of humanity in response to an increase in extremes will be far less tangible and more difficult to assess. In the case that no political action is taken to limit global mean surface temperature warming to the targets defined in the Paris Agreement, the temperature and water availability of the Mediterranean may resemble that of the Sahara Desert by the end of the twenty-first century (Jones et al. 2018). Furthermore, under the RCP8.5/SSP5-8.5 scenario and using the same metric, much of Africa, Australia, Amazonia and South East Asia will experience climates that are outside the envelope of what currently exists on Earth, they have simply not been experienced in human history (Jones et al. 2018; Almazroui et al. 2020a, b). Under such circumstances, mass migration would seem inevitable with subsequent socio-economic impacts that are difficult to predict.

If there is even the slightest chance that governments will attempt to deploy SRM in future decades to limit global warming and its consequences, then there is a pressing need now to do more research in this area to develop a deeper understanding. In other words, if antipyretic medication might need to be administered, then there needs to be more detailed knowledge of its benefits and contraindications. In parallel, and as national lockdowns and confinements will come to an end after the COVID-19 pandemics, governments should take immediate measures and a modest fraction of the current global stimulus funds (Andrijevic et al. 2020) to speed up clean energy transitions, boost energy resilience and to put the world on track to achieve the Paris Agreement goals, so that humanity would come out of this crisis in a much better position than they were before.
Acknowledgements This comment was written as a result of discussions at the 2019 Riederalp workshop on climate extremes (https://ccia.ch/riederalp2019/). Anthony Jones is thanked for his useful comments and discussions during the writing of this article. The authors acknowledge funding from a Universities of Geneva-Exeter Collaborative Research Seed Grant.

Funding Open access funding provided by University of Geneva.

\section{Compliance with Ethical Standards}

Conflict of interest The authors declare that they have no known competing financial interests or personal relationships that could have appeared to influence the work reported in this comment.

Open Access This article is licensed under a Creative Commons Attribution 4.0 International License, which permits use, sharing, adaptation, distribution and reproduction in any medium or format, as long as you give appropriate credit to the original author(s) and the source, provide a link to the Creative Commons licence, and indicate if changes were made. The images or other third party material in this article are included in the article's Creative Commons licence, unless indicated otherwise in a credit line to the material. If material is not included in the article's Creative Commons licence and your intended use is not permitted by statutory regulation or exceeds the permitted use, you will need to obtain permission directly from the copyright holder. To view a copy of this licence, visit http://creativecommons.org/licenses/by/4.0/.

\section{References}

Almazroui M, Saeed F, Saeed S, Islam MN, Ismail M, Klutse NAB, Siddiqui MH (2020) Projected change in temperature and precipitation over Africa from CMIP6. Earth Syst Environ 4:455-475. https://doi.org/10.1007/s41748-020-00161-x

Almazroui M, Saeed S, Saeed F, Islam MN, Ismail M (2020) Projections of precipitation and temperature over the South Asian countries in CMIP6. Earth Syst Environ 4:297-320. https://doi. org/10.1007/s41748-020-00157-7

Andrijevic M, Schleussner C-F, Gidden MJ, McCoolum DL, Rogelj J (2020) COVID-19 recovery funds dwarf clean energy investment needs. Science 370(6514):298-300. https://doi.org/10.1126/scien ce.abc9697

Atif RM, Siddiqui HM, Almazroui M (2020) Near-real-time spatiotemporal analysis of convection and extreme rainfall leading to a flash flood using MSG-SEVIRI and TRMM data: a case study of a flash flood in Jeddah, Saudi Arabia on the November 25, 2009. J Flood Risk Manage 13:e12611. https://doi.org/10.1111/jfr3.12611

Barbier EB (2020) Greening the post-pandemic recovery in the G20. Environ Resour Econ 76:685-703. https://doi.org/10.1007/s1064 0-020-00437-w

Carbon Brief (2020) Analysis: What impact will the coronavirus pandemic have on atmospheric $\mathrm{CO}_{2}$. https://www.carbonbrief.org/ analysis-what-impact-will-the-coronavirus-pandemic-have-onatmospheric-co2

Brown C, Alexander P, Arneth A et al (2019) Achievement of Paris climate goals unlikely due to time lags in the land system. Nat Clim Chang 9:203-208. https://doi.org/10.1038/s41558-019-0400-5

Forster PM, Forster HI, Evans MJ et al (2020) Current and future global climate impacts resulting from COVID-19. Nat Clim Chang 10:913-919. https://doi.org/10.1038/s41558-020-0883-0 
Haywood JM, Jones A, Bellouin N, Stephenson D (2013) Asymmetric forcing from stratospheric aerosols impacts Sahelian rainfall. Nat Clim Chang 3:660-665. https://doi.org/10.1038/nclimate1857

Henry MS, Bazilian MD, Markuson C (2020) Just transitions: Histories and futures in a post-COVID world. Energy Res Soc Sci 68:101668. https://doi.org/10.1016/j.erss.2020.101668

Houghton JT, Meira FLG, Bruce JP, Lee H, Callander BA, Haites EF (Eds) (1995) Climate change 1994: radiative forcing of climate change and an evaluation of the IPCC 1992 IS92 emission scenarios. Cambridge University Press. IPCC (2018) Summary for Policymakers of IPCC Special Report on Global Warming of $1.5^{\circ} \mathrm{C}$ approved by governments.

IPCC (2020) https://archive.ipcc.ch/ipccreports/tar/wg1/531.htm. Accessed 5 Oct 2020

Irvine PJ, Keith DW (2020) Halving warming with stratospheric aerosol geoengineering moderates policy-relevant climate hazards. Environ Res Lett 15(4):044011. https://doi.org/10.1088/17489326/ab76de

Irvine P, Emanuel K, He J et al (2019) Halving warming with idealized solar geoengineering moderates key climate hazards. Nat Clim Chang 9:295-299. https://doi.org/10.1038/s41558-019-0398-8

Jones A, Haywood JM, Boucher O (2009) Climate impacts of geoengineering marine stratocumulus clouds. J Geophys Res 114:D10. https://doi.org/10.1029/2008JD011450

Jones A, Haywood JM, Boucher O (2011) A comparison of the climate impacts of geoengineering by stratospheric $\mathrm{SO}_{2}$ injection and by brightening of marine stratocumulus cloud. Atmos Sci Letter 12:176-183. https://doi.org/10.1002/asl.291

Jones A, Haywood JM, Alterskjær K et al (2013) The impact of abrupt suspension of solar radiation management (termination effect) in experiment G2 of the Geoengineering Model Intercomparison Project (GeoMIP). J Geophys Res Atmos 118:9743-9752. https://doi.org/10.1002/jgrd.50762

Jones AC, Haywood JM, Dunstone N et al (2017) Impacts of hemispheric solar geoengineering on tropical cyclone frequency. Nat Commun 8:1382. https://doi.org/10.1038/s41467-017-01606-0

Jones AC, Hawcroft MK, Haywood JM et al (2018) Regional climate impacts of stabilizing global warming at $1.5 \mathrm{~K}$ using solar geoengineering. Earth's Futur 6:230-251. https://doi. org/10.1002/2017EF000720

Jones A, Haywood JM, Jones AC, Tilmes S, Robock A, Kravitz B (2020) North Atlantic Oscillation response in GeoMIP experiments G6solar and G6sulfur: Why detailed modelling is needed for understanding regional implications of solar radiation management. Atmos Chem Phys Discuss. https://doi.org/10.5194/ acp-2020-802

Kharin VV, Flato GM, Zhang X et al (2018) Risks from climate extremes change differently from $1.5^{\circ} \mathrm{C}$ to $2.0^{\circ} \mathrm{C}$ depending on rarity. Earth's Futur 6:704-715. https://doi.org/10.1002/2018E F000813

Knutson T, Camargo SJ, Chan JCL et al (2020) Tropical cyclones and climate change assessment part II: Projected response to anthropogenic warming. Bull Am Meteorol Soc 101:E303E322. https://doi.org/10.1175/BAMS-D-18-0194.1

Kravitz B, Robock A, Boucher O, Schmidt H, Taylor KE, Stenchikov G, Schulz M (2011) The geoengineering model intercomparison project (GeoMIP). Atmos Sci Lett 12(2):162-167. https://doi. org/10.1002/asl.316

Kravitz B, Caldeira K, Boucher O et al (2013) Climate model response from the Geoengineering Model Intercomparison Project (GeoMIP). J Geophys Res Atmos. https://doi.org/10.1002/ jgrd.50646

Kravitz B, MacMartin DG, Visioni D, Boucher O, Cole JNS, Haywood JM, Jones A, Lurton T, Mills MJ, Nabat P, Niemeier U, Robock A, Séférian R, Tilmes S (2020) Comparing different generations of idealized solar geoengineering simulations in the Geoengineering Model Intercomparison Project (GeoMIP). Atmos Chem Phys Discuss. https://doi.org/10.5194/ acp-2020-732

Latham J, Bower K, Choularton T, Coe H, Connolly P, Cooper G, Craft T, Foster J, Gadian A, Galbraith L, Iacovides H (2012) Marine cloud brightening. Phil Trans Royal Soc A 370(1974):4217-4262. https://doi.org/10.1098/rsta.2012.0086

Lawrence MG, Schäfer S, Muri H, Scott V, Oschlies A, Vaughan NE, Boucher O, Schmidt H, Haywood J, Scheffran J (2018) Evaluating climate geoengineering proposals in the context of the Paris Agreement temperature goals. Nat Comm 9:3734. https://doi. org/10.1038/s41467-018-05938-3

Le Quéré C et al (2020) Temporary reduction in daily global CO2 emissions during the COVID-19 forced confinement. Nat Clim Chang 10:647-653. https://doi.org/10.1038/s41558-020-0797-x

Malavelle FF, Haywood JM, Jones A et al (2017) Strong constraints on aerosol-cloud interactions from volcanic eruptions. Nature 546(7659):485-491. https://doi.org/10.1038/nature22974

Masson-Delmotte V, Zhai P, Pörtner H-O, et al (2018) Global warming of $1.5^{\circ} \mathrm{C}$. An IPCC Special Report. Cambridge University Press, Cambridge

Myhre G, Alterskjær K, Stjern CW, Hodnebrog Ø, Marelle L, Samset BH, Sillmann J, Schaller N, Fischer E, Schulz M, Stohl A (2019) Frequency of extreme precipitation increases extensively with event rareness under global warming. Sci Rep 9:16063. https://doi.org/10.1038/s41598-019-52277-4

Nakicenovic N, Grübler A, Gaffin S et al (2003) IPCC SRES revisited: a response. Energy Environ 14:187-214. https://doi. org/10.1260/095830503765184592

Niemeier U, Timmreck C (2015) What is the limit of climate engineering by stratospheric injection of $\mathrm{SO}_{2}$ ? Atmos Chem Phys 15:9129-9141. https://doi.org/10.5194/acp-15-9129-2015

NOAA (2020) https://www.esrl.noaa.gov/gmd/ccgg/trends/data.html. Accessed 5 Oct 2020

Ou S, He X, Ji W et al (2020) Machine learning model to project the impact of COVID-19 on US motor gasoline demand. Nat Energy 5:666-673. https://doi.org/10.1038/s41560-020-0662-1

Parson EA (2017) Climate policymakers and assessments must get serious about climate engineering. Proc Natl Acad Sci U S A 114(35):9227-9230. https://doi.org/10.1073/pnas.1713456114

Robock A, Marquardt A, Kravitz B, Stenchikov G (2009) Benefits, risks, and costs of stratospheric geoengineering. Geophys Res Letter 36(19). https://doi.org/https://doi.org/10.1029/2009G L039209

Robock A, Bunzl M, Kravitz B, Stenchikov GL (2010) A test for geoengineering? Science 327(5965):530-531. https://doi. org/10.1126/science. 1186237

Robock A, MacMartin DG, Duren R, Christensen MW (2013) Studying geoengineering with natural and anthropogenic analogs. Clim Change 121(3):445-458. https://doi.org/10.1007/s1058 4-013-0777-5

Rosenbloom D, Markard J (2020) A COVID-19 recovery for climate. Science 368(6490):447. https://doi.org/10.1126/science.abc48 87

Royal Society (2009) Geoengineering the climate: science, governance and uncertainty. Royal Society, UK, p 98

Sachs JD, Schmidt-Traub G, Williams J (2016) Pathways to zero emissions. Nat Geosci 9:799-801. https://doi.org/10.1038/ ngeo 2826

Schewe J, Gosling SN, Reyer C et al (2019) State-of-the-art global models underestimate impacts from climate extremes. Nat Commun 10:1005. https://doi.org/10.1038/s41467-019-08745-6

Schubert J (2019) Measuring, Modeling, Controlling the Climate? Numerical Expertise in U.S. Climate Engineering Politics. In: Markus J. Prutsch (ed.). Science, Numbers and 
Politics, Springer. p. 181-202. https://doi.org/https://doi. org/10.1007/978-3-030-11208-0

Showstack R (2013) Carbon dioxide tops 400 ppm at Mauna Loa, Hawaii. Eos, Trans Am Geophys Union 94(21):192. https://doi. org/10.1002/2013eo210004

Soden BJ, Wetherald RT, Stenchikov GL, Robock A (2002) Global cooling after the eruption of Mount Pinatubo: a test of climate feedback by water vapor. Science 296(5568):727-730. https:// doi.org/10.1126/science.296.5568.727

Stjern CW, Muri H, Ahlm L et al (2018) Response to marine cloud brightening in a multi-model ensemble. Atmos Chem Phys 18:621-634. https://doi.org/10.5194/acp-18-621-2018

Stoffel M, Khodri M, Corona C et al (2015) Estimates of volcanicinduced cooling in the Northern Hemisphere over the past 1500 years. Nat Geosci 8:784-788. https://doi.org/10.1038/ngeo2526

Tabari H (2020) Climate change impact on flood and extreme precipitation increases with water availability. Sci Rep 10:13768. https://doi.org/10.1038/s41598-020-70816-2
Tay CWJ, Yun SH, Chin ST et al (2020) Rapid flood and damage mapping using synthetic aperture radar in response to Typhoon Hagibis. Japan Sci Data 7:100. https://doi.org/10.1038/s4159 7-020-0443-5

Tilmes S, Sanderson BM, O’Neill BC (2016) Climate impacts of geoengineering in a delayed mitigation scenario. Geophys Res Lett 43(15):8222-8229. https://doi.org/10.1002/2016GL070122

Toll V, Christensen M, Quaas J, Bellouin N (2019) Weak average liquid-cloud-water response to anthropogenic aerosols. Nature 572(7767):51-55. https://doi.org/10.1038/s41586-019-1423-9

Trisos CH, Amatulli G, Gurevitch J et al (2018) Potentially dangerous consequences for biodiversity of solar geoengineering implementation and termination. Nat Ecol Evol 2:475-482. https://doi. org/10.1038/s41559-017-0431-0

Yiwei J, Fu J, Li B, Zhou F (2020) Increased extreme hourly precipitation over China's rice paddies from 1961 to 2012. Sci Rep 10:10609. https://doi.org/10.1038/s41598-020-67429-0 